\title{
The role of social media in the collaboration, interaction, co-creation and co-delivery of a
}

\section{social venture in an uncertain conflict environment}

\section{Cherry W M Cheung, London South Bank University}

101 London Road, London, UK. cheungc5@1sbu.ac.uk. Cherry Cheung is a senior lecturer and the group lead of the Business Ethics \& Corporate Social Responsibility Research Group at the Business School of London South Bank University. Her research interests include religion and entrepreneurship, social entrepreneurship, enterprise education, business law and entrepreneurship amongst those with Autism Spectrum Disorder/ Condition.

Caleb C Y Kwong, University of Essex

10 Elmer Approach, Southend-on-Sea, Essex, UK. ckwong@essex.ac.uk. Caleb Kwong is a reader and the undergraduate director of the Management Science and Entrepreneurship Group, Essex Business School, University of Essex. His current research interests include social entrepreneurship, entrepreneurship at the time of war and conflict, refugee entrepreneurship, and entrepreneurship amongst those with Autism Spectrum Disorder/ Condition.

Charan Bhattarai, Loughborough University London.

3 Lesney Avenue, The Broadcast Centre, Here East Queen Elizabeth Olympic Park, London, UK. Charan Bhattarai is a part time lecturer at Loughborough University London. He has a $\mathrm{PhD}$ with the University of Essex, on social entrepreneurship.

\begin{abstract}
This research case study examines the creation and development of a bottom-up social enterprise immediately after the outbreak of a civil war in an Arab country by a group of young patriots in the aftermath of the Arab Spring uprisings in the 2010s. Drawing on Linders' (2012) model of social action lifecycle, our study examines how different actors become involved and co-created a socially entrepreneurial venture (SEV), how these actors contributed to the coproduction and co-delivery of the social actions (values) over time, and how social media play roles in these processes. Drawing from the empirical evidences of citizen co-production within the existing literature, we found that SEVs operate in very different ways in which the role of social media is critical, both from their equivalents operating in a penurious but stable environment, and those intending to pursue political action within a conflict situation. In our case study, social media was not intended for mass-mobilisation, but for selected mobilisation amongst those within the network. This is due to the insecure environment and the fear of infiltration from opposing parties. We also examine how new actors were, over time, being carefully screened and selected, and potential harmful existing players being excluded, which in turn contributed to the evolving nature of the social enterprises.
\end{abstract}

Keywords: Interaction, collaboration, uncertainty, war and conflict, social entrepreneurship, youth 


\section{$1 \quad$ Introduction}

With over 125 violent conflicts recorded worldwide since the end of the Cold War, killing an estimate of seven million people (Banfield et al, 2006), the understanding of the specific focus on the conflict context is empirically crucial. Conflict situations often bring about the destruction of buildings, infrastructure and communication networks, but most importantly of all, people, families and communities. Repairing this damage often requires swift collective, socially entrepreneurial actions. Existing research has examined the behaviours of 'volunteer citizens' at a time of emergency (Wenger, 1991), suggesting that it is often those who feel physically, culturally or cognitively close to those being affected by the emergency situation are most likely to want to get involved, to help out or contribute in any way they can to the relief and subsequent rebuilding process (Lowe and Fothergill, 2003). Self-organised initiatives by these compassionate 'volunteer citizens' include the formation of socially entrepreneurial ventures (SEVs) (Miller, Grimes, McMullen and Vogus, 2012), which can be loosely defined as innovative, social value-creating entrepreneurial activities addressing 'unsolvable' social problems particularly focusing on neglected social issues amongst groups that are marginalised within mainstream societies (Bornstein, 2007; De Clerq and Honig, 2011; Lewis, 2013). Such entities can bring relief and supports, and are increasingly being seen to have a key role to play in the rebuilding process in emerging situations such as those arising in the aftermath of natural disasters (Lewis, 2013).

Scholars have highlighted the important roles of social media in the co-creation of such entities for the co-production of political (Rainie et al., 2012) and social actions (Bertot, Jaeger and Grimes, 2010; Lovejoy and Saxton, 2012; Segerberg and Bennett, 2011) in a stable environment. Scholars have also highlighted the roles of social media for the co-creation of political movements and co-production of political actions in a resource-poor and unstable environment (Tufekci and Wilson, 2012; Valenzuela, 2013; Wolfsfeld, Segev and Sheafer, 
2013). However, despite such important roles of social media in the co-creation of SEVs for addressing complex social issues in penurious environments and complex political issues in resource-poor and unstable environments, scholars have still overlooked the importance of the study of how social media play roles for the co-creation of SEVs and co-production of social actions (values) in a resource-poor and unstable environment such as war and conflict zones. Scholars have long considered that entrepreneurship is a context dependent social process (Ireland et al., 2003; Low and Abrahamson,1997). Thus, entrepreneurship is different in the context of war and conflicts than it is in the context of stable environment (Cheung and Kwong, 2017). Similarly, social entrepreneurship could be different in different contexts. Hence, it is crucial to study social entrepreneurship in the context of war and conflicts. Drawing on Linders' (2012) model of social action lifecycle, our study will answer the following research questions.

a How do different actors become involved and co-create a socially entrepreneurial venture (SEV) in a resource-poor and unstable environment? And what roles do social media play in this process?

b How do the different actors of SEVs contribute to the co-production and co-delivery of the social actions (values) over time in a resource-poor and unstable environment? And what roles do social media play in this process?

We aim to answer these questions by an in-depth case study (Dubois and Gadde, 2002) of an SEV operating in a war and conflict zone and by considering social media as a particular channel by which actors communicate for the co-creation of SEVs and co-production of socially entrepreneurial actions. 'Social media' refers to "a set of online tools that are designed for and centred around social interaction" [(Bertot, Jaeger and Hansen, (2012), p. 30], and it includes social networking sites such as Facebook, MySpace and Twitter (Bertot, Jaeger and 
Hansen, 2012; Kaplan and Haenlein 2010; O'Keeffe and Clarke-Pearson, 2011). 'Co-creation' simply refers in this study to the creation of SEVs by the affected people and for the affected people in the penurious environment. Similarly, 'co-production' refers to the production of social action (values) by the affected people and for the affected people in the penurious environment.

We argue that our research focus is original for two reasons. Firstly, previous studies tend to assume that the war and conflict environment is only one variant of the penurious environment, with the majority of studies on social media focusing on the generation of citizento-citizen (C2C) socially entrepreneurial actions amongst resource-poor, but stable contexts. Furthermore, prior literature has focused on the creation of socially entrepreneurial ventures mostly in the context of a resource-poor but stable environment (developed countries) (e.g. Corner and Ho 2010; Di Domenico, Haugh and Tracey, 2010). We, on the other hand, acknowledge some major similarities between the resource-poor and unstable environment (war and conflicts) and the resource-poor but stable environment, but also identify considerable differences between them for the creation and operation of ventures (Anderson, Markides and Kupp, 2010). Secondly, although studies have looked into the use of social media and the mobilisation of protestors for political actions, very few have focused on how it mobilises collective social rather than political actions. The existing studies on the mobilisation of political actions tend to acknowledge that the use of social media is often limited to the dissemination of information and the airing of discontent through online outlets, rather than for physical collective action (He and Warren, 2011; Morozov, 2011). We argue that user-led participation in social media does often go beyond the dissemination of information or the airing of discontent, but there are more dynamic mechanisms for the co-creation and codelivery of change.

In this study, we explore how and when different actors are mobilised through social 
media and, in the process, co-create a new SEV intending to offer social action to those in need. We then further examine the co-delivery process and in particular, the logistical communication for socially entrepreneurial actions. We also explore how, over time, the network within the social media communication chain evolves, and, when combined with change in an external context, results in further evolution of the nature of the SEV in the longer run.

We found that social media forms a key role in the co-creation of the SEV and coproduction of socially entrepreneurial actions. Unlike in previous studies where social media is often limited to an information dissemination role, we also found that it plays a key role in the actual organisation of the SEV and in particular, the logistics of communication among different actors within the chain.

The remainder of the paper is organised as follows: the next two sections discuss the existing literature on the role of social media in the co-creation and co-delivery of social actions, before focusing specifically on a conflict situation. We then proceed to discuss methodology, before presenting the results, then finally, the conclusion.

\section{Social Media and the co-creation of SEVs and co-production and co-delivery of collective social entrepreneurial actions}

The entrepreneurship literature has moved away from its initial emphasis on a personal, solitary entrepreneurship journey, and towards a network view, placing an increasing emphasis on social embeddedness whereby different actors are brought together through the sharing of certain meanings and understandings (Downing, 2005; Granovetter, 2000; Jack and Anderson, 2002; Jack et al., 2008). Scholars have linked social embeddedness to opportunity creation (Jack and Anderson, 2002), access to financial resources (Uzzi, B., 1999), application of new venture ideas (Simsek, Lubatkin and Floyd, 2003), and nature of entrepreneurship and the 
behaviours of entrepreneurs (Welter and Smallbone, 2011). Thus, the social contexts can influence social innovation and social entrepreneurship (Newth and Woods, 2014). Moreover, Di Domenico, Haugh and Tracey [(2010), p. 690)] acknowledge the important roles of society and community in the creation of socially entrepreneurial ventures.

Increasingly, studies have also explored how social media can generate collective C2C actions (Guo and Saxton, 2014; Obar, Zube and Lampe, C., 2012; Segerberg and Bennett, 2011), and how it is crucial for the formation and development of SEVs (Korsgaard and Anderson, 2011; Lewis, 2013). Facilitated by improvements and the increasingly widespread availability of information and communication technologies, social media form an increasingly popular platform where individuals sharing similar causes can interact and communicate in a "polychronic way" [(Lee and Liebenau, (2002), p. 132], thereby promoting collaboration between them (Cameron and Webster, 2005; Yamamoto, 2006). Such an open platform facilitates the exchange of information, expands participation in discussion forums to those with more diverse backgrounds and who are more geographically dispersed, and allows different individuals to contribute in their own way (Amichai-Hamburger, 2008; Linders, 2012). Wikipedia, for instance, is often viewed as one such example where individuals develop a distributed peer production network that requires minimal financial input. Crowdsourcing is another means where users are gathered by an online platform to co-create a specific project or product, an example of which could be Gooseberry Path, which utilised its community to create a series of cookbooks. By allowing discussion and feedback, social media can also promote group identity construction, which is an antecedent for action (Valenuela, 2013).

For co-production of socially entrepreneurial action to succeed in the long term, the ability to sustain a social initiative beyond the initial generation of interest is crucial. Beyond information dissemination, Linders' (2012) model of social action lifecycle categorises the cocreation and co-production process into three sequential stages: i) design and planning, ii) 
delivery and execution, and iii) monitoring and evaluation, which are elaborated further in Table 1.

*** Insert Table 1 about here***

3. The context of paucity, war and conflict, and the role of social media under such conditions

Conventionally, conflict is categorised as a form of penurious environment (Gelditsch et al., 2006), which conveniently is also the contextual bracket within which social entrepreneurships are traditionally being placed (Le Billion, 2001). 'Social entrepreneurship' describes the activities of grass-roots activists and others, which address social issues in innovative and creative ways (Nicholls, 2008). Similarly, Chell (2007, p.11) states that social entrepreneurship is underpinned by 'pro-social motives that drive the primary mission'. Hence, the SEV that focuses less on profits or financial returns and more on both the innovation and sustainability is a social enterprise (Chell 2007; Lewis, 2013). Within such a bracket of paucity where resources are severely constrained, SEVs are being hailed for their ability to offer novel products, services and supports to communities and markets that have been previously neglected by the free market due to limited financial returns (Leadbeater, 1997; Thompson, 2002). Such an ability is often attributed to superior localised, tacit knowledge that helped reducing uncertainties and costs (Santos, 2012). It indicates a clear shift of thinking towards bottom-up initiatives (O’Reilly, 2010).

Literature on $\mathrm{C} 2 \mathrm{C}$ co-production has generally pointed to the difficulty for individuals to effectively co-ordinate and self-organise $\mathrm{C} 2 \mathrm{C}$ social actions and in particular, the difficulties in managing a multifaceted and vast interaction chain between different actors (Osbourne, 2010). Many C2C social actions such as Neighbourhood Watch would not survive without governmental supports. Therefore, government supported social media platform is often seen 
as crucial for C2C SEVs to prosper (Linders, 2012). Such supports include the Government 2.0 taskforce in Australia, the 'Government-with you' model in Singapore, or the Open Government Directive in the US, where the government often offers a platform for citizens to use co-governance through providing resources, setting rules, and mediating disputes, but leaving room for citizens and other non-profit organisations to do the heavy-lifting (Linders, 2011).

Nevertheless, the literature in the context of conflict environments receives little attention (Wolfsfeld et al., 2013). Conflict situations present a triple whammy of challenges that are unique and different from other forms of penurious environment. First of all, the resultant destruction from conflicts attributed to the intensification of social problems and the number of people in need of immediate support (Pennebaker and Harber, 1993; Summerfiel, 1998). Secondly, war and conflict created a situation where the distribution of power and responsibility has shifted drastically away from the state (Rummel, 1977; Singer, 2003). Thirdly, international relief agencies may struggle to enter conflict environments to offer supports (Duffield, 1997).

Studies have found that social media can play a major role in contributing to collective actions at a time of conflict. For instance, tech-savvy protestors used social media to let their voices be heard during the Arab Spring (Bruns et al., 2013; Gladwell and Shirky, 2011; Shirky, 2011). However, it has often been noted that the use of social media has not been able to provide strategic, interactive, organisational communication or act as a stakeholder engagement tool amongst organisations intending to mobilise political actions (Saxton et al., 2007), but merely gives users a false sense of participation ('slacktivists') that had minimal effect on social outcome (He and Warren, 2011; Morozov, 2009).

*** Insert Table 2 about here*** 
Literature on political activism suggests that conflict situations present enormous challenges for the organisers of political actions to obtain the type of information that is necessary for the effective mobilisation of social action. Lemert (1981) argued that mobilising actors requires three types of information, which are summarised in Table 2. Studies have found that challenges in obtaining information via social media have restricted it to information dissemination and the airing of discontent, while the organisation of the actual logistics of managing political actions and protests remains largely off-line (Lotan et al., 2011). We explore in this study how SEVs access and manage the identification, locational and tactical information about actors and themselves for co-producing social actions in war and conflict zones where confidentiality of this information is crucial. Furthermore, studies found notable differences between the different forms of social media, with the particular focus on inclusivity versus exclusivity. The benefits and drawbacks of the respective forms are highlighted in Table 3. From the discussion in this section, we also come up with a graphical representation of our conceptual framework (Figure 1).

\footnotetext{
*** Insert Table 3 about here***

*** Insert Figure 1 about here***
}

\section{The research context}

The research context of this study concerns the uprisings which occurred in one Arab country that was affected by the Arab Spring. To protect the respondents' identities we apply the pseudonym 'Zaman' throughout. The context is a typical one during the Arab Spring: citizens opposed to a long-serving autocratic regime, initially leading to a short series of mass antigovernment protests that were quickly suppressed by the military. Such protests quickly transformed into a number of opposition bodies forming rebel groups, who armed themselves through various means. This eventually led to a full-scale civil war resulting in a significant 
period of bloodshed. The conflict has resulted in considerable instability within the whole country, with the country becoming segmented and falling into the control of different militia groups. One notable consequence is that the collapse of the national economic system and the destruction of physical, transport and communication infrastructures by warfare have considerably affected the livelihood of the majority of people within the country, with the most severely affected being those who lived within some of the key strategic cities where battles are constantly being fought between different parties.

The context of conflict presents a number of social challenges in relation to this research. Firstly, many people wanted to get out of the dangerous situation that they faced within the conflict zone. A considerable proportion of houses, physical infrastructures and communication channels have been destroyed and many of them live without water, electricity, or an operating sewage system. Most problematic of all, the state of lawlessness was a constant endangerment to their lives, their communities, and their livelihood. All these problems led to mass exodus occurring in many parts of the conflict zone. Providing them with a safe passage, however, is easier in theory than in practice according to previous research (Weissman, 2004). Secondly, once they are out of the conflict zone, there is a question of how best to provide basic relief, the people who have fled their home towns having lost their home, possessions and livelihood, and therefore providing such relief is crucial (Weiss and Collins, 2000). Thirdly, there is the question of livelihood rebuilding, and in particular, how to ensure that their competencies can be best utilised in a related or even a different profession. Studies have suggested that this can be done through employment but also through self-employment, through skill and capacity building but also through the provision of microfinance (Banfield et al, 2006). Instead of offering goods and services as donations to the individuals, who are affected by warfare, offerings them a loan to start up an employment or a venture would provide sustainable solutions not only for the beneficiaries but also providing financial self-sufficiency 
to the ventures that offer the loan. Microfinance is considered to be an alternative option for individuals with lack of resources to start up a venture (Newman, Schwarz, and Borgia, 2014) as it does not require physical collaterals to access finances or loans, which is a crucial resource to start up and grow a venture. Therefore, through micro financing, SEVs can significantly contribute to solve the social problems as well as can be financially sustainable.

It is also important to note that the situation of warfare and its consequences has captured media attention worldwide, accompanied by widespread discussion on social media such as Facebook and Twitter in both Arabic and English. Scholars (Sacco and Bossio, 2015, p. 59) argue that 'the dynamism of social media creates opportunities for fast news dissemination, pluralised voices in reportage, and extended audience reach'. The ruling regime faced condemnation from political leaders and other influential figures, initially for how the protest was being handled, and then the approach it took to suppress the subsequent unrest. At the grassroots level, netizens have expressed considerable anger both towards the regime and also about the lack of action taken by the UN. The emotional outpouring of grief and despair was collective, with well-wishers from across the world choosing different ways to support the situation. Some well-wishers support the cause through donations to international relief agencies that became actively involved, but many were unable to reach those in need due to logistical and safety concerns. Studies (Toole and Waldman, 1990) show that most of the international development agencies, although they have adequate resources and capabilities, still failed to provide necessary supports to internally displaced population. Consequently, the unmet needs of the displaced population still remain (Kim et al., 2007). Therefore, others who feel more strongly, in particularly netizens who came from the country of the conflict as well as those who migrated elsewhere, became involved through more active means, and our case was born out of such a desire amongst such a group. Converting these concerns into the creation of a sustainable socially entrepreneurial venture for the creation and delivery of socially 
entrepreneurial actions providing sustainable solutions to the problems of those individuals who are affected and displaced by the war and conflicts. This is the area that this paper is intending to explore further.

\section{$5 \quad$ Methodology}

The research method that we adopted for this study is a single case analysis. The single case analysis has long been established in the literature as one of the research strategies (Eisenhardt and Graebner, 2007; Eisenhardt, 1989). We followed closely the approach adopted by Lewis (2013), in a study that focused on a single social organisation in terms of how it emerged in the context of a natural disaster and evolved over time. We found considerable similarities between the context of the study and ours, particularly in the emergent context, its unpredictability, and the mass supports associated with it. Furthermore, our study is 'revelatory', as it aims to explore the creation and development of socially entrepreneurial venture in the context of war and conflict, for which scholars (Becker, 2012; Ghauri, 2004, p. 7) suggest that 'a single case design is appropriate'. Therefore, we consider the approach adopted in this paper a fitting one to follow.

Our research began after a chance encounter in a local entrepreneurship workshop between a researcher and one of the co-founders of the SEV that was operating in a war and conflict zone. Then, following the convenience sampling method (Etikan, Musa, and Alkassim 2016), we selected the SEV as our single case and the co-founder as one of the interviewees in

this research. Given the ongoing war and conflicts, resulting restrictions of the movement of people and their lack of security, in the country where the SEV was located, the adoption of convince sampling method is appropriate in this study. The cofounder of the SEV had left the country some time before. The researchers had a long initial discussion about the nature of the SEV and through the discussion and communications they developed trust to each other. This 
person then acted as the focal point for accessing information, consistent with the approach adopted by Lewis (2013). As with Lewis (2013), the voice of the entrepreneur is the focal point of the study. The person also provided valuable secondary information to the researchers, including access to the group's Facebook content. Indeed, If we had not adopted this approach, we wouldn't have been able to obtain any information (Atkinson and Flint, 2001), given the context of war and conflicts in which 'the entire population is marginalized to some degree, making it 'hidden' from and 'hard to reach' from the outside because the conflict develops distrust and suspension among the population, particularly, with the outsiders (Cohen and Arieli, 2011). The personnel we discussed with involved in the roles as co-founder, treasurer, outreach worker, and foreign member of the SEV. This allowed us to gain a complete picture of the SEV and it is consistent with a recent study of Bacq, Janssen, and Noël (2017). As the SEV remains in operation we anonymized data collection, cleaning and analysis stages to avoid potential ramifications, consistent with Kaiser (2009). Whilst Lewis (2013) did not anonymise the identities of the country, organisation, and interviewees, the different context that we faced (war and conflict) led us to omit the specific contexts in relation to the country and major locations of their operation. Instead, country-neutral pseudonyms that were chosen by one of the co-founders are used. These include Zaman (the name of the country), Moanabi (the capital that remains under the government's control), Mimas, Salam, Nawaer and Jabal (provincial cities affected by the conflict). In addition, some of the factual information has also been moderately altered to protect the identity of the SEV and the people within it, without affecting the arguments in the study. Consistent with the prior similar, qualitative, case studies based, social entrepreneurship research (Bacq, Janssen, and Noël, 2017), the interviews were complemented by secondary information. These include internet searches of the stories in association with the SEV and its context including Facebook group contents, newspaper and magazine articles, other social media platforms, and the personal blogs of relevant personnel. 
Furthermore, following the purposive sampling principle (Etikan, Musa, and Alkassim 2016), we also conducted additional interviews with personnel who had expertise on the socio, economic, and political environment of the area and the country where the SEV was located and operated. The information obtained from them enabled us to triangulate (Suri, 2011) and then complement the date obtained from the SEV. Following the notion of information sufficiency (Saunders and Townsend, 2016, p., 837), we realised that the information obtained from interviewing those involving in roles representing and covering different areas of the SEV, additional experts as well as the data obtained from secondary sources was sufficient to achieve our research purpose.

Two rounds of coding were adopted. First, a-priori codes (themes) were developed in accordance with Linder's (2012) categorisation. Once responses were allocated to these general themes, sub-themes were then created in each category (Table 4). The main purpose of the adoption of Linder's (2012) model and categorisation in this study is to facilitate us to understand whether the creation and development of socially entrepreneurial ventures in resource-poor and unstable environment caused by war and conflicts follow the similar pattern to the creation and development of such ventures in stable environment.

\footnotetext{
*** Insert Table 4 about here***
}

\section{$6 \quad$ Findings}

\subsection{Idea generation}

The SEV started when three friends used Facebook to discuss what they could do to help. All three are from the country concerned and, at the time, lived in that country. Two were from Montabi, the capital that remains under government control, and the other was originally from Mimas, a provincial city, which became the stronghold of the rebels and a main focal point of 
the subsequent conflict. They considered a number of ideas for relief work and, after some discussion, eventually settled on a temporary rehoming scheme to allow the displaced persons to be housed in vacant properties across the country that were considered safe:

When the conflict started in Mimas, people were starting to flee the city and going into cities that were safer, such as Motanbi. One issue that occurred to us was that these people needed shelter. Many of them were homeless, without anything. Some people in these cities began to lend out their spare houses. Some rich people may have three houses and they don't use them, or only for rental.

However, at the time this was only done on an ad-hoc basis and the distribution process was inefficient. Displaced persons who arrived from the conflict areas often had limited contacts with those willing to offer support. In addition, there was also hesitancy from the potential lenders as there were concerns as to whether they were legitimate refugees or simply opportunists. What occurred to the group members was that the process could be done more systematically and efficiently:

We realised that we could gather information on the people who own these houses and the people who need these houses. We can keep a registry of it and do the matching, with no payment.

The logical point to start the initiative was to operate between the cities where the co-founders were based, Mimas and Motanbi. Once the venture was up and running they began to share their initiative with friends online and joined forces with them. The majority were students and expatriates from outside the country, living across the world. Eventually, with the mix of people within the group they settled to operate between three points: the two already mentioned, and Salam, a further provincial city that was under siege by government forces: 
At the beginning of the conflict, support was pouring in for these people because they are from Zaman and they empathised with them. We had people outside the country fund raising amongst the local communities in the country where they were based. As we received more funding and manpower as supports, we were trying to grow. In addition to the three cities mentioned, we also expanded into a fourth and fifth city that are considered safe places. People operating in these cities provided these new families not only with shelter, but also bedding, blankets, clothes, food baskets and other essentials. At the time, no NGOs had started operating in Zaman.

\subsection{Design and planning}

At the design and planning stage, a number of issues had to be considered, including the following:

\subsubsection{Platform selection}

The platform chosen was Facebook, the reason being that Facebook offers anonymity to members. The government became more suspicious of citizen involvement, especially if it involved people travelling out of the rebel-controlled areas. This led to tighter controls with many people being arrested. Concern for safety led to the choice of Facebook over other forms of social media such as Twitter:

Protecting the identity of our participants is key. We decided to choose Facebook as our operation platform because of the closed group function, which enabled us to screen those who wished to join. Each of the original participants adopts a pseudonym Facebook profile and an email account specifically for working for the SEV.

Facebook was used for a number of functions including news dissemination, idea discussion and providing a record. These include important financial and transaction documents. Newsfeeds only got deleted if they involved conflict between individuals, as it could cause 
disharmony. For security reasons, they never put real personal information, phone numbers and other personal details online. Whilst the major part of the collaboration was conducted on Facebook and Skype, traditional email and phones were also in use.

\subsubsection{Member selection}

Initially the door was kept relatively open. One of the interviewees said that two of the friends just joined the Facebook group. Later as the conflict intensified, new membership was restricted to those who were already connected to the existing members, who then acted as the verifier of the person's identity. One of the co-founders explained:

There is a node. For instance, me. Then there are four people from my school, my undergrad, so they are real, sincere people I really know. I know they will not harm us and tell our secrets to outsiders. These four people, each one, is a node to another three or four people. So we started with three. I added a member who I think will be very helpful and safe and eventually we grew bigger and bigger. Therefore even if I don't trust you, I trust your friend... The central co-ordinator verifies each of the pseudonym profiles requesting to join. The co-ordinator will ask the node, 'Who is he? How did you know him? Do you know his house, his family? Where is he? Where did he study?' We do not need his name, just that you know him. So if you think he can be trusted, then we will add him... There are many members whose real name I still don't know... You cannot add someone who you or your close friends do not know personally.

At the time of the interview there were $80-82$ members within the SEV.

\subsubsection{Relationship with the government}

One of the decisions that they had to make was the relationship that they intended to have with the government. Most SEVs registered with the government were offered the legitimacy and freedom to operate within any government controlled territories, including those with restricted 
access. Additionally, it allowed them to operate openly, and to have a legitimate presence both physically and online. Furthermore, it enhanced their marketing functions, increasing their ability to fundraise and to obtain resources through other means. The downside of government association, however, was that the government may want to interfere and direct the targeted recipients, focusing on their political supporters. At the same time, opposing forces may perceive the organisation as hostile to their cause and may equally hinder their work in the rebel controlled area. This provided them with a major dilemma at the formation stage. The decision was that the SEV should remain apolitical. Nevertheless, according to the co-founder:

Although our organisation is apolitical, our members tend to lean towards the revolution side and share a strong resentment towards the government. Most felt uneasy working with the government, with many attributing the chaos and unrest to the way the government handled the situation. Some even participated actively in protests or even more. Therefore it would not be wise for our organisation to become registered with the government.

It was a difficult decision for them because the SEV essentially functioned between the conflict zone and government controlled territories, but was one that had to be made for the safety of their members. Once this political line was drawn, it also affected their subsequent recruitment target, as they began to screen out government supporters and sympathisers. It has also affected their strategy towards their operation:

The government knows about us, it's not that they don't know. But sometimes you walk clear of the boundary, then it is okay, but you shouldn't do anything that threatens them...We deliberately keep low key and operate largely undercover. We also deliberately keep small because the bigger we are, the more attention we will draw from the government, which could endanger our operation. 


\subsubsection{Safeguarding mechanisms}

However, working without government registration presents a threat to the long term survival of the SEV. There have been incidents in the past where the government infiltrated similar operations, resulting in their leading figures being found and their operations closed down. Consequently, the SEV took a number of steps to tighten up their safeguarding procedures.

During operations, a number of different codes and passwords were also used. Explaining the rationale:

When we talk we have to use codes. I mean we can't say 'I have a family here and I really need a house', because the government may intercept these things. Even if they discover that you are helping vulnerable families, they can take you and ask if you do that and a lot of other things. Because these families lived in a place that is against the government, and therefore helping them means you must be against the government, kind of. Therefore we should keep things secret.

The SEV also had to confront the danger of infiltration, as explained below:

In the first two years the government was catching lots and lots of people. Members may have been taken away by the government who then assumed an identity online. Normally their arrest is not about us, but their participations in political protests or other actions. They want to find out exactly who these people have been in contact with, and the activities that they have been involved in. Sometimes they would start by contacting other unsuspecting members, to find out who they are and what they are doing. Therefore if someone had been arrested then our online activities would eventually have been found out. Leaving them in would jeopardise the safety of the whole group and we cannot afford that. 
To prevent this, the SEV always told their members to be vigilant, and never to trust online contacts without verification. When a conversation became suspicious, contact was cut off and the co-ordinator was told. A number of safeguarding procedures were put in place, as explained below:

The co-ordinator is in possession of the log-in details of the pseudonym Facebook profile of each member. If they heard that a member had been arrested, then they would delete the account immediately. If a member had not been responsive for a while, they would try to contact them and, without response after trying both their real Facebook profile and phone, they would immediately take them out of the group for precautionary reasons.

\subsection{Delivery and execution}

\subsubsection{Setting the delivery blueprint}

Although the SEV started with a re-homing initiative, they continued to experiment with a number of social projects. To do so they needed a dynamic set up that induces innovation and facilitates change. Additionally, they need to access to resources. Specifically, due to being in the host location, it is crucial for them to collaborate with local individuals to access to local resources, and with outsiders to access to advanced knowledge and competencies in order to successfully create social projects and deliver social values. A co-founder explained their approach in more detail and described a largely bottom-up decision structure in deciding on the projects to pursue:

After about a year into the conflict, other NGOs and other organisations started helping too... We don't want to compete. We want to identify market gaps so when other people start working on it, we moved on to other projects. Our projects keep changing as the composition of the people and situation changes. Everyone's skills are utilised to create 
new ideas. We rely a lot on the insiders for their local information and observations, and outsiders for their other knowledge and competencies. We go for multiple objectives at a time, and we circulate and discuss the ideas on Facebook. We go directly to the relevant members for each project - 'Do you want to be part of this or not?' - and of course anyone else can express interest. The structure is flexible. Sometimes local ideas are implemented locally. Each member has their own projects. For instance, members in Germany are helping local members there. We go with the flow of the members. If no one is interested in an idea or have strong reasons against it, then we will move against it. We only make decisions on critical issues, or, when there are too many opinions, then the co-founders will make executive decisions.

\subsubsection{Workload distribution}

Alongside the co-founders who make executive decisions but otherwise take a low-key role, the main roles within the SEV include the co-ordinator, outreach workers and foreign members.

Co-ordinator - The co-ordinator is one of the founders and the de-facto Chief Executive Officer within the SEV. The person is responsible for coordinating the transactions of money between local outreach workers on one hand, and foreign members on the other.

Outreach workers - The outreach workers are responsible for most of the groundwork. They will be involved in the distribution of money as well as looking for people who need to be helped. They are also there to assess their needs, and decide on how best the SEV can offer support. They will also consider the eligibility of the recipients and make decisions accordingly. According to the person involved in outreach:

I would say we were mostly working part time. For a day, if there is a serious issue it would take around three hours. But we are kind of working all of the time as at any time someone may have an issue or want something so we have to be available all the time... 
at the beginning it was crazy. I was working eight hours, I was even working until 12am, typing online, even on the phone... I start typing a lot using internet all the time, I even had pains in my nerves. There are so many families sitting in the street without any houses. People will be calling, and say, there is a family of six, five kids, no man, so we need to put them somewhere.

The outreach worker therefore plays a highly essential and substantive role in the SEV. The person has the discretionary power to make executive decisions once on the case. For instance, as the organisations began to expand, the challenge of the lack of housing began to emerge. It became the responsibility of the bottom-up initiatives by the outreach workers to source housing through different means. In one case:

After two to three months of conflict, a lot of people came in as most of the houses are already full. We start renting houses and paying for the houses for these people, collecting the money through donations, some from inside Zaman and some outside Zaman.

As the demand for housing was increasing rapidly but the resources (such as the houses that the local individuals were willing to offer them to temporarily shelter the displaced population) were very limited. In such a resource constraint situation, they need to utilise the resources that were at hands and the resources that were discarded or originally developed for other purposes in order to support the displaced people. In another case, they found innovative and costeffective way to obtain housing:

The government closed down a lot of schools, but good things happened. Neighbourhoods started opening up these schools, and now every classroom has a family (living there). 
Nevertheless, as people are beginning to settle, outreach workers are also responsible to deal with emerging challenges. For instance:

All these people living in the same place means trouble. People will fight for money, food, a lot of bad things are going on so they need to organise them. So someone had to organise within these schools.

Senior outreach workers also assume the role of local treasurer and therefore possess financial power over how the money is to be distributed and work very closely with the coordinator through social media.

Foreign members - These are expatriates, students or displaced persons who are now based in a foreign country. Their main roles include raising donations, building awareness amongst the expatriate communities, and brainstorming in terms of organising new activities or strategies to get to newly needed locations. They are also responsible for connecting with other support bodies or relief organisations working in the country of conflict, as it is often easier to make connections once they are free from political intervention. These are mostly localised initiatives without top-down interference, since they are the income generation outlets. There will be a treasurer responsible for finance but money exchange can take place between foreign members and the co-ordinator directly.

\subsubsection{Rule setting and procedural issues}

At the beginning the organisation had no expectations regarding the kind of rules that would help improve the efficiency of the operation, or safeguard individuals' interests, and consequently there were very few explicit rules. As time goes by, new rules begin to emerge to formalise practices. These are often triggered by 'critical incidents', when things have gone wrong. For instance, a co-founder recalled: 
At the beginning we had an easy-going attitude towards collaboration. Members help each other in their own projects, two members say to each other, 'I need some money for a family here', and connect with each other without informing us as the managers. That had led to some financial transparency problems and arguments. Since then we (the co-founder and the co-ordinator) decided that we needed to control the money flow, and that we needed to be informed in case something happened. We don't stop them, but we don't encourage them to directly deal with each other.

At other times these rules are introduced due to funding constraints. The outreach worker, for instance, who was in charge of the distribution of supports, recalled how eligibility rules have been set:

We had limited funding and with the increased number we want to reach the vulnerable families first. I had to take the painful decision that families with men will not receive any support after months into our programme. It was kind of cruel. It was a very hard decision for me personally as I was responsible for distributing the money and the families see me. I first gave them notice. I had to say to them that, look, you are a strong man, and you can feed your family, and you need to find a job. We tried to do it gradually so once they became more settled, we started reducing the support provided to make them feel that they need to get a job and be independent. Even for families with only women and children, we ask them to work. They can work from home.

\subsubsection{Financial organisation and management}

The co-ordinator takes a lead role in the financial organisation and management. All the money from the different fundraising activities will be channelled to the co-ordinator, who is based in a neighbouring Arab country that is not an ally of the ruling regime in Zaman. The money is then smuggled into Zaman, the rationale of which is explained below by an ex-Treasurer: 
If you transfer money into Zaman, the one who received money will get a lot of questions from the government. Sometimes people will be jailed just for that. We have a secure method to bring the money into Zaman without being detected.

Once in Zaman, the money is distributed to various local treasurers, who decide on how the money will be spent locally. The co-ordinator is also involved in bookkeeping, and keeps a record of all transactions that are being kept offline. Every week the co-ordinator will be in dialogue with both the foreign workers and local treasurers, usually through email. Details of all transactions between country treasurers and co-ordinators are uploaded onto Facebook to maintain transparency. There are always a few people working on the same project for monitoring and balance. Families who do not receive money any month can call the senior outreach worker to find out what has happened. They can also ask for a receipt. The co-founder admitted that it is always possible to abuse the system; it is felt that trust is the main issue.

\subsection{Monitoring and evaluation}

6.4.1 Reflecting on changes in the external context

The SEV closely monitored how the external context has changed over time. From very early on the SEV realised that it cannot stand still, and needs to react to changes on a number of fronts. According to a co-founder:

After about a year into the conflict, other NGOs and other organisations started helping (relief work) too. But our services also started changing by that point. We noticed that people need books, because the school year had started, the students start a new year in a new city, and their parents do not have money to pay. We collected second-hand textbooks which does not require a large budget... (then) we started with medicine. We then collected money to buy medicine and connect with those who are in possession of 
medicine (hospital, pharmacy, doctors, etc). It is a similar project to the rehoming scheme where we connected people who need medicine and those who have medicine.

\subsubsection{Reflecting on changes in the internal context}

The SEV also bears in mind some of the internal structural issues within their existing projects. As the number of the beneficiaries increase, they began to realise that their current relief model was unsustainable. Support has decreased as the warfare continues and people begin to lose interest. They had to reduce the funding support for those who are less vulnerable as mentioned previously, but in doing so they realised the next challenge is to help them to become integrated into society, most importantly through employment. New initiatives begin to emerge tackling the integration and employment issues:

After the initial three months period, families with men are moved on to the employment support scheme. We sit down with them to discuss what they would like to do, and push them to find a job. We help them to make connections with relevant people. But most importantly, some of them have been in the cities for nearly 2 years so they should make their own connection with their neighbours, and with work.

Through doing so they also realised the importance of setting themselves up through financial support:

We give them the money to start buying all the things they need in order to get a job.

Whilst financial support for employment enables better integration, nevertheless, the SEV's need for sustainability remains. They began to experiment with other models of support, such as collaboration with other partners, for example, with donors and funders. One of the models is through matching donors with families that are in need of employment support: 
The donor specifies the amount that he has, whether it is a grant, a one-off loan, or a recycled loan, and the type of projects he wants the money to be spent on. He matches their funds with the most appropriate recipients, who will be given the money to carry out a specific employment project. Afterwards we report to the donor regularly about the progress that the recipient is making towards the project.

The advantage of such a model is that the SEV is no longer required to bear all the costs in association with the support, and instead merely act as the middleman between the two. Another advantage is the financial transparency of this approach, as evidence of progress can be backed up by photographic evidence as well as the actual contact with the recipients. Donors feel engaged because they feel more involved when supporting an actual family rather than giving money to a cause where they have no idea where the money has been spent. Once they established that the demand for finance is high, the SEV began to experiment with other models, most notably microfinance. This has also proved popular amongst overseas donors. Since then they have received an increase in donations for support. This enabled them to make more loans, as well as bigger loans than previously.

\subsubsection{Reflecting on changes in the personnel context}

The number of members within Zaman continued to reduce due to conflict. Many of the people have left, and this has caused operational problems:

We now only have ten people within Zaman and therefore finding people to do fieldwork is difficult. I was an outreach worker and it was extremely difficult to find a replacement. Before I left I had to spend three months to train one girl who was completely new. I had to meet all the families with her, as they would not trust new people. She is now also responsible for the local treasury. 
The scope of groundwork activities that they can participate in has reduced considerably. In particular, they have now pulled out of operating in one of the original cities they operated in, because they do not have anyone living there anymore. Nevertheless, this was not considered to be a problem:

We do as much as we can. The number of people that we were dealing with is decreasing anyway. People are kind of settled down. They are no longer living in the middle of a war, they live in a safe environment which is not $100 \%$ safe, but at least they have a home, they know where they will be the next day so they are not homeless.

With the reduced groundwork involvement, the SEV is beginning to turn to the role of mediation between those who offer support and those who require support. As discussed above, the cases of medicine, second hand books and also loans for the poor are largely adopting this particular model.

Many of the people who are now outside Zaman continue to be involved, but in different capacities. According to the person who used to involve as treasurer:

The people who are now outside Zaman are now trying to fundraise, increase awareness, and take on advisory and supporting roles such as to design for the different campaigns. So we can do less in Zaman now, but the good thing is that they can now bring in more money.

One emerging opportunity that they now notice is that these overseas members can now offer more extensive supports to new entrants to different countries. A person who operated as foreign member recalls:

Many of our members who are overseas have good jobs and can offer advice to new entrants to the country that they are now based in. For instance, in a neighbouring Arab country, they advise them on how to find jobs, where to go to buy essential goods, and 
places and scams to avoid to reduce danger. Many people had their money taken with the promise of a job that never materialised. For instance, locals may promise to give the refugees papers (work and residential documents) in exchange for money. Others in Germany, for instance, use our webpage as a forum to search for flats (to enable new entrants to settle). Some utilise their good language skills to translate relevant papers and articles from foreign sources. Some people who have obtained scholarships help others to obtain scholarships. They are a peer support group, not just helping outsiders but also each other.

Another advantage is that, through the collaboration with foreign members, the SEV is being exposed to new ideas, techniques, and skills beyond what is available locally. The idea of turning towards the microfinance model, for instance, is the result of one of the co-founders, who, having left the country, by chance encountered the concept through a business ideapitching platform. Through the employment of the concept of microfinance, the SEV turned in self-sufficient socially entrepreneurial venture. Although they were already operating a microloan scheme, the mentioning of the term 'microfinance' by one of the panel members opened the SEV up to a set of new literature and practices that they were not aware of in the first place.

\section{Discussions and conclusion}

Our case demonstrates the co-creation of one SEV and its journey in co-producing and codelivering social actions in a penurious and unstable conflict environment, eventually turning their efforts into a financially sustainable social venture. We believe that the contribution of the paper lies with a further understanding of the way in which SEVs can be co-created and the SEVs can co-create and co-produce social action, in a unique and restrictive conflict context, through utilising social media. Utilising the framework provided in Linders (2012), our study provides further understanding of the collaboration and interaction process between actors 
within such a context. Our results demonstrate that the use of social media facilitates the SEV in each of the stages in the model of the social action lifecycle (Linders, 2012). Therefore, social media, as Flanagin et al. (2006) suggested, enabled the SEV to collapse time and reduce hierarchical restraints, allowing actors, in a more efficient and cost-effective way, to mobilise, co-create and co-produce social actions. Such advantages can be found in both the 'design and planning' and the 'delivery and execution' stages within Linders' framework.

We found that the experience of the SEV during the 'monitoring and evaluation' stage is consistent with other entrepreneurial firms in the literature (Baron, 2006), in that it is change orientated and able to quickly shift from one idea to the next in a highly entrepreneurial manner. Throughout the process they show that they are flexible, with new projects and initiatives emerging according to contextual changes. Additionally, we found that bricolage is the strategy the SEV employs to overcome the resource constraint conditions, which is consistent with the study of Di Domenico et al. (2010) on social enterprises in penurious environment. Our finding is also consistent with Segerberg and Bennett (2011) which suggests that social media facilitates a much more flexible approach to enable wider participation in the co-creation of new initiatives and projects over time. This enables the SEV to draw on both the local knowledge of the local workers, as well as the competencies, ideas and knowhow of members across the world. This enables the SEV to continuously innovate and adapt to changes and challenges. Highlighting the crucial roles of local knowledge in the operation and development of a venture, the findings of our study is in line with the study of Cheung and Kwong (2017) in the context of war and conflict.

Compared to the empirical evidences found within the citizen co-production literature, we found that our SEV operated in a unique way, compared to their equivalents operating in penurious but stable environments, as well as those intending to pursue political action within the conflict situation (see Table 2). In our case, social media was not intended for mass- 
mobilisation, but for selected mobilisation amongst those within the network. This is due to the insecure environment and the fear of infiltration from opposing parties. Considerable efforts have also been made to protect those already within the network through the adoption of ritual and other subtle monitoring practices.

*** Insert Table 5 about here***

Twitter is by default the popular choice of empirical study in the context of mobilising political action within conflict situations (Burns et al., 2013), and government platforms for C2C social action in a penurious but stable environment (O'Reilly, 2011). Our study demonstrates that in a context where government support is minimal, free social platforms such as Facebook emphasising exclusivity can be considered as a cost-effective alternative to the above. It offers a platform with essential operational functions to enable actors to discuss, manage and monitor in a manner similar to those on the government's platform. Such a platform is important for social rather than political action because social actions require much more intensive, long term collaboration between a manageable number of actors and require articulation of the details in the execution. In contrast, political action emphasises information dissemination for mass mobilisation, often for a series of, but nevertheless, stand-alone events to generate a strong voice to be heard. We also found that, compared with Twitter, Facebook's emphasis on exclusivity provides actors with a much more secure platform where social actions can be managed and the protests can be made by those involved, without serious political ramifications. By offering such insights about how contexts influence the creation, operation, and development of a socially entrepreneurial venture, this study significantly contributes to the entrepreneurship literature. Furthermore, entrepreneurship scholars have long been stating that there is a huge gap of qualitative research in the literature of entrepreneurship (Hindle, 2004; Hlady-Rispal and Jouison-Laffitte, 2014), which this study contributes to fill. 
In terms of our managerial contribution, our study highlights the possible ways in which social media can enable 'volunteer citizens' to get together in addressing pressing social issues in an unstable, ever-changing and politically sensitive environment. We helped identify challenges faced by these 'volunteer citizens' throughout the co-creation and co-delivery processes, and, through the example of our particular SEV, illustrate how overcoming these challenges may be possible through utilising a cost-effective social media platform such as Facebook. This would enable aspiring 'volunteer citizens' to learn from these challenges and think of how these can be overcome in their own specific context.

In terms of future direction, it would be interesting to explore the challenges where access to social media is rare or restricted, where studies have suggested that netizens and activists operating within such environments tend to move very quickly between different social media platforms (Qiang, 2011; Sullivan 2011). It would be interesting to see whether organising SEVs such as the one identified in this study would still be possible.

Our study also focuses on only one form of social media, Facebook, and it would be interesting to see how other social media platforms can be adapted for the process. As this study only considers the experience of one SEV, a quantitative study exploring the co-creation and co-delivery processes utilising an enriched sample size would enable the idea to be further generalised.

\section{References}

Amichai-Hamburger, Y. (2008) 'E-empowerment: Empowerment by the Internet', Computers in Human Behaviour, Vol. 24, No. 5, pp.1773-1775.

Anderson, J.L., Markides, C. and Kupp, M. (2010) 'The last frontier: Market creation in conflict zones, deep rural areas, and urban slums', California Management Review, Vol. 52, No. 4, pp.6-28. 
Atkinson, R. and Flint, J. (2001) 'Accessing hidden and hard-to-reach populations: Snowball research strategies', Social Research Update, Vol. 33, No.1, pp.1-4.

Bacq, S., Janssen, F. and Noël, C. (2017) 'What Happens Next? A Qualitative Study of Founder Succession in Social Enterprises' Journal of Small Business Management, Advance online publication, doi: doi:10.1111/jsbm.12326

Banfield, J., Gunduz, C. and Killick, N (Eds.), (2006) 'Local business, local peace: The peacebuilding potential of the domestic private sector', International Alert, London.

Baron, R.A. (2006) 'Opportunity recognition as pattern recognition: How entrepreneurs "connect the dots" to identify new business opportunities', The Academy of Management Perspectives, Vol. 20, No. 1, pp.104-119.

Bazeley, P. and Jackson, K. [Eds.], (2013) Qualitative data analysis with NVivo, Sage Publications Limited, London.

Beinhocker, E.D. (2006) ‘The adapcorporation', McKinsey Quarterly, No. 2, p.76-87.

Becker, H. S. (2012). 'Expert voice'. In S. E. Baker and R. Edwards, How Many Qualitative Interviews are Enough? Na- tional Centre for Research Methods Review Discussion Paper, p. 15. Retrieved from http://eprints.ncrm.ac.uk/2273/ (accessed 11 February 2018). 
Bertot, J.C., Jaeger, P.T. and Hansen, D. (2012) 'The impact of polices on government social media usage: Issues, challenges, and recommendations', Government Information Quarterly, Vol. 29, No. 1, pp.30-40.

Bertot, J.C., Jaeger, P.T. and Grimes, J.M. (2010) 'Using ICTs to create a culture of transparency: E-government and social media as openness and anti-corruption tools for societies', Government Information Quarterly, Vol. 27, No. 3, pp.264-271.

Bornstein, D. (2007) How to change the world: Social entrepreneurs and the power of new ideas, Oxford University Press, Oxford.

Biernacki, P. and Waldorf, D. (1981) 'Snowball sampling: Problems and techniques of chain referral sampling', Sociological Methods \& Research, Vol. 10, No. 2, pp.141-163.

Bruns, A., Highfield, T. and Burgess, J. (2013) 'The Arab spring and social media audiences English and Arabic twitter users and their networks', American Behavioral Scientist, Vol. 57, No. 7, pp.871-898.

Bullough, A., Renko, M. and Myatt, T. (2014) 'Danger zone entrepreneurs: The importance of resilience and self-efficacy for entrepreneurial intentions'. Entrepreneurship Theory and Practice, Vol. 38, No. 3, pp.473-499.

Cameron, A.F. and Webster, J. (2005) 'Unintended consequences of emerging communication technologies: Instant messaging in the workplace', Computers in Human Behavior, Vol. 21, No. 1, pp.85-103.

Chell, E. (2007) 'Social enterprise and entrepreneurship towards a convergent theory of the entrepreneurial process', International Small Business Journal, Vol. 25, No. 1, pp.5-26. 
Cheung, C.W.M. and Kwong, C. (2017) 'Path-and place-dependence of entrepreneurial ventures at times of war and conflict', International Small Business Journal, Vol. 35, No. 8, pp.903-927.

Cohen, N. and Arieli, T. (2011) 'Field research in conflict environments: Methodological challenges and snowball sampling', Journal of Peace Research, Vol. 48, No. 4, pp.423-435.

Corner, P.D. and Ho, M. (2010) 'How opportunities develop in social entrepreneurship', Entrepreneurship Theory and Practice, Vol. 34, No. 4, pp.635-659.

De Clercq, D. and Honig, B. (2011) 'Entrepreneurship as an integrating mechanism for disadvantaged persons', Entrepreneurship and Regional Development, Vol. 23, No. 5-6, pp.353-372.

Di Domenico, M., Haugh, H. and Tracey, P. (2010) 'Social bricolage: Theorizing social value creation in social enterprises', Entrepreneurship Theory and Practice, Vol. 34, No. 4, pp.681703.

Downing, Stephen (2005) 'The social construction of entrepreneurship: Narrative and dramatic processes in the coproduction of organizations and identities', Entrepreneurship Theory and Practice, Vol. 29, No. 2, pp.185-204.

Dubois, A. and Gadde, L.E. (2002) 'Systematic combining: an adductive approach to case research', Journal of Business Research, Vol. 55, No. 7, pp.553-560.

Duffield, M. (1997) 'NGO relief in war zones: towards an analysis of the new aid paradigm', Third World Quarterly, Vol. 18, No. 3, pp.527-542. 
Eisenhardt, K.M. (1989) 'Building theories from case study research', Academy of Management Rreview, Vol.14, No. 4, pp.532-550.

Eisenhardt, K.M. and Graebner, M.E. (2007) 'Theory building from cases: Opportunities and challenges' Academy of Management Journal, Vol. 50, No. 1, pp.25-32.

Etikan, I., Musa, S.A. and Alkassim, R.S. (2016) 'Comparison of convenience sampling and purposive sampling', American Journal of Theoretical and Applied Statistics, Vol. 5, No. 1, pp.1-4.

Fearon, J. (2008) 'Economic development, insurgency, and civil war', in Elhanan, H. (eds.), Institutions and Economic Performance, Harvard University Press, Cambridge, MA, pp.292328.

Flanagin, A.J., Stohl, C. and Bimber, B. (2006) 'Modeling the Structure of Collective Action 1 This material is based upon work supported by the National Science Foundation under Grant No. 0352517. The authors are equal contributors to this article', Communication Monographs, Vol. 73, No. 1, pp.29-54.

Frank, H. and Lueger, M. (1997) 'Reconstructing development processes: conceptual basis and empirical analysis of setting up a business', International Studies of Management and Organization, Vol. 27, No. 3, pp.34-63.

Ghauri, P., 2004. Designing and conducting case studies in international business research. Handbook of qualitative research methods for international business, pp.109-124. 
Available

at:https://scholar.google.co.uk/scholar?start=20\&q=single+case + study + research $+\% 2 B+$ numb $\underline{\text { er }+ \text { of }+ \text { interviews\&hl }=\text { en\&as } \_s d t=0,5}$ (Accessed on 08/02/2018).

Giddens, A. (1984) The constitution of society: Outline of the theory of structuration, University of California Press, Oakland, California.

Gil de Zdñiga, H., Jung, N. and Valenzuela, S. (2012) 'Social media use for news and individuals' social capital, civic engagement and political participation', Journal of Computer - Mediated Communication, Vol. 17, No. 3, pp.319-336.

Gilbert, E. and Karahalios, K. (2009) 'Predicting tie strength with social media' in Proceedings of the SIGCHI conference on human factors in computing systems, ACM, New York, pp. 211220.

Guo, C. and Saxton, G.D. (2014) 'Tweeting social change: How social media are changing non-profit advocacy', Nonprofit and Voluntary Sector Quarterly, Vol. 43, No. 1, pp.57-79. Granovetter M. (2000) 'The economic sociology of firms and entrepreneurs', in Swedberg R. (ed.), Entrepreneurship: A social science view, Oxford University Press, Oxford, New York, pp.244-275.

Gleditsch, N.P., Furlong, K., Hegre, H., Lacina, B. and Owen, T. (2006) 'Conflicts over shared rivers: Resource scarcity or fuzzy boundaries?', Political Geography, Vol. 25. No. 4, pp.361382.

Gladwell, M. and Shirky, C. (2011) 'From innovation to revolution', Foreign Affairs, Vol. 90, No. 2, pp.153-154. 
Greve, A. and Salaff, J.W. (2003) 'Social networks and entrepreneurship', Entrepreneurship Theory and Practice, Vol. 28, No. 1, pp.1-22.

Guo, C. and Saxton, G.D. (2014) 'Tweeting social change: How social media are changing nonprofit advocacy', Nonprofit and Voluntary Sector Quarterly, Vol. 41, No.1, pp.57-79.

Hanna, R., Rohm, A. and Crittenden, V.L. (2011) 'We're all connected: The power of the social media ecosystem', Business Horizon, Vol. 54, No. 3, pp. 265-273.

He, B. and Warren, M.E. (2011) 'Authoritarian deliberation: The deliberative turn in Chinese political development', Perspectives on politics, Vol. 9, No. 2, pp.269-289.

Hindle, K. (2004) 'Choosing qualitative methods for entrepreneurial cognition research: A canonical development approach', Entrepreneurship Theory and Practice, Vol. 28, No. 6, pp.575-607.

Hlady-Rispal, M. and Jouison-Laffitte, E. (2014) 'Qualitative research methods and epistemological frameworks: A review of publication trends in entrepreneurship', Journal of Small Business Management, Vol. 52, No. 4, pp.594-614.

Hoffman, D.L. and Fodor, M. (2010) 'Can you measure the ROI of your social media marketing?', MIT Sloan Management Review, Vol. 52, No. 1, pp.4-49. 
Hite, J.M. and Hesterly, W.S. (2001) 'The evolution of firm networks: From emergence to early growth of the firm', Strategic Management Journal, Vol. 22, No. 3, pp.275-286.

Ireland, R.D., Hitt, M.A., Camp, S.M. and Sexton, D.L. (2001) 'Integrating entrepreneurship and strategic management actions to create firm wealth' The Academy of Management Executive, Vol. 15, No. 1, pp.49-63.

Ireland, R.D., Hitt, M.A. and Sirmon, D.G. (2003) 'A model of strategic entrepreneurship: The construct and its dimensions' Journal of Management, Vol. 29, No.6, pp.963-989.

Jack, S.L. and Anderson, A.R. (2002) 'The effects of embeddedness on the entrepreneurial process', Journal of Business Venturing, Vol. 17, No. 5, pp.467-487.

Jack, S., Dodd, S.D. and Anderson, A.R. (2008) 'Change and the development of entrepreneurial networks over time: a processual perspective', Entrepreneurship and Regional Development, Vol. 20, No. 2, pp.125-159.

Johannisson, B. (1996) 'The Dynamics of Entrepreneurial Networks', in P. D. Reynolds et al (eds.), Frontiers of Entrepreneurship Research, Babson College, Boston, MA, pp. 253-267.

Johannisson, B. and Mønsted, M. (1997) 'Contextualizing entrepreneurial networking: The case of Scandinavia', International Studies of Management and Organization, Vol. 27, No. 3, pp.109-136.

Kaplan, A.M. and Haenlein, M. (2010) 'Users of the world, unite! The challenges and opportunities of Social Media', Business Horizons, Vol. 53, No. 1, pp.59-68.

Kaiser, K. (2009) 'Protecting respondent confidentiality in qualitative research', Qualitative Health Research, Vol. 19, No. 11, pp.1632-1641. 
Korsgaard, S. and Anderson, A.R. (2011) 'Enacting entrepreneurship as social value creation', International Small Business Journal, Vol. 29, No. 2, pp.135-151.

Le Billon, P. (2001) 'The political ecology of war: natural resources and armed conflicts', Political Geography, Vol. 20, No. 5, pp.561-584.

Leadbeater, C. (1997) The rise of the social entrepreneur, Demos, London.

Lee, H. and Liebenau, J. (2002) 'A New Time Discipline: Managing Virtual work environment', in Whipp, et al (Eds.), Making time: Time and Management in Modern Organizations, Oxford University Press, Oxford.

Lemert, J.B. (1981) 'Does mass communication change public opinion after all?: a new approach to effects analysis', Nelson-Hall Inc., Chicago, IL.

Lewis, K.V. (2013) 'The power of interaction rituals: The Student Volunteer Army and the Christchurch earthquakes', International Small Business Journal, Vol. 31, No. 7, pp.811-831.

Linders, D. (2012) 'From e-government to we-government: Defining a typology for citizen coproduction in the age of social media', Government Information Quarterly, Vol. 29, No. 4, pp.446-454.

Linders, D. (2011) 'We-Government: an anatomy of citizen coproduction in the information age', In Proceedings of the 12th Annual International Digital Government Research Conference: Digital Government Innovation in Challenging Times, ACM, College Park, Maryland, pp. 167-176.

Lotan, G., Graeff, E., Ananny, M., Gaffney, D. and Pearce, I. (2011) 'The Arab Spring| the revolutions were tweeted: Information flows during the 2011 Tunisian and Egyptian revolutions', International Journal of Communication, Vol. 5, pp.1375-1405. 
Lovejoy, K. and Saxton, G.D. (2012) 'Information, community, and action: how nonprofit organizations use social media', Journal of Computer - Mediated Communication, Vol. 17, No. 3, pp.337-353.

Low, M.B. and Abrahamson, E. (1997) 'Movements, bandwagons, and clones: Industry evolution and the entrepreneurial process', Journal of Business Venturing, Vol. 12, No. 6, pp.435-457.

Lowe, S. and Fothergill, A. (2003) 'A need to help: Emergent volunteer behavior after September 11 ${ }^{\text {th }}$, Beyond September 11th: An account of post-disaster research', Boulder, CO: Natural Hazards Research and Applications Information Center, University of Colorado, pp.293-314.

Miller, T.L., Grimes, M.G., McMullen, J.S. and Vogus, T.J. (2012) 'Venturing for others with heart and head: How compassion encourages social entrepreneurship' Academy of Management Review, Vol. 37, No. 4, pp.616-640.

Moon, J.Y., and Sproull, L.S. (2008) 'The role of feedback in managing the Internet-based volunteer work force', Information Systems Research, Vol.19, No. 4, pp.494-515.

Morozov E. (2007) 'The new frontier in human rights', Transitions Online [Online] 27 April. https://www.ceeol.com/search/article-detail?id=46310 (Accessed 15 October, 2016).

Nah, S. and Saxton, G.D. (2012) 'Modeling the adoption and use of social media by nonprofit organizations', New Media and Society, Vol. 15, No. 2, pp.294-313.

Newman, A., Schwarz, S. and Borgia, D. (2014) 'How does microfinance enhance entrepreneurial outcomes in emerging economies?', The mediating mechanisms of 
psychological and social capital, International Small Business Journal, Vol. 32, No. 2, pp.158179.

Newth, J. and Woods, C. (2014) 'Resistance to social entrepreneurship: How context shapes innovation' Journal of Social Entrepreneurship, Vol. 5, No. 2, pp.192-213.

Nicholls, A. (Ed.), (2008) Social entrepreneurship: New models of sustainable social change. Oxford University Press, Oxford.

Obar, J.A., Zube, P. and Lampe, C. (2012) 'Advocacy 2.0: An analysis of how advocacy groups in the United States perceive and use social media as tools for facilitating civic engagement and collective action' Journal of Information Policy, Vol. 2, pp.1-25.

O'Keeffe, G.S. and Clarke-Pearson, K. (2011) 'The impact of social media on children, adolescents, and families', Pediatrics, Vol. 127, No,4, pp.800-804.

Ostrom, M. (2006) 'Everyday meanings of "local food": Views from home and field', Community Development, Vol. 37, No. 1, pp.65-78.

O'Reilly, T. (2011) ‘Government as a Platform’, innovations, Vol. 6, No. 1, pp.13-40.

O'Reilly, D. and Reed, M. (2010) “'Leaderism': an evolution of managerialism in UK public service reform', Public Administration, Vol. 88, No. 4, pp.960-978.

Osborne, S.P. (Ed.), (2010) The new public governance: Emerging perspectives on the theory and practice of public governance, Routledge, London.

Papacharissi, Z. (Ed.), (2010) A networked self: Identity, community, and culture on social network sites. Routledge, London. 
Pennebaker, J.W. and Harber, K.D. (1993) 'A social stage model of collective coping: The Loma Prieta earthquake and the Persian Gulf War', Journal of Social Issues, Vol. 49, No. 4, pp.125-145.

Rainie, L., Smith, A., Schlozman, K.L., Brady, H. and Verba, S. (2012) 'Social media and political engagement', Pew Internet \& American Life Project. [online]. http://pewinternet.org/ /media//Files/Reports/2012/PIP_SocialMediaAndPoliticalEn gagement_PDF.pdf. (Accessed 15 October 2016).

Rummel, R.J. (1977) Understanding conflict and war: Vol. 3: Conflict in perspective, Sage Publication, Beverly Hills, $\quad$ California. http://www.hawaii.edu/powerkills/NOTE12.HTM\#ACK. (Accessed 16 October 2016)

Sacco, V. and Bossio, D. (2015) 'Using social media in the news reportage of War \& Conflict: Opportunities and Challenges' The Journal of Media Innovations, Vol. 2, No. 1, pp.59-76.

Santos, F.M. (2012) 'A positive theory of social entrepreneurship', Journal of Business Ethics, Vol. 111, No. 3, pp.335-351.

Saunders, M.N. and Townsend, K. (2016) 'Reporting and justifying the number of interview participants in organization and workplace research', British Journal of Management, Vol. 27, No. 4, pp.836-852.

Saxton, G.D. (2007) 'Social capital and vitality of community based organisations', Paper presented at the Annual Meeting of the Western Academy of Management, Missoula, MT, 2124 March. 
Segerberg, A. and Bennett, W.L. (2011) 'Social media and the organization of collective action: Using Twitter to explore the ecologies of two climate change protests', The Communication Review, Vol. 14, No. 3, pp.197-215.

Simsek, Z., Lubatkin, M.H. and Floyd, S.W. (2003) 'Inter-firm networks and entrepreneurial behavior: A structural embeddedness perspective', Journal of Management, Vol. 29, No. 3, pp.427-442.

Singer, P.W. (2003) 'War, profits, and the vacuum of law: privatized military firms and international law', Columbia Journal of Transnational Law, Vol. 42, No. 2, pp.521-549.

Shirky, C. (2011) 'The political power of social media', Foreign Affairs, Vol. 90, No.1, pp.2841.

Smith, A.N., Fischer, E. and Yongjian, C. (2012) 'How does brand-related user-generated content differ across YouTube, Facebook, and Twitter?', Journal of Interactive Marketing, Vol. 26, No. 2, pp.102-113.

Summerfield, D. (1998) 'The social experience of war and some issues for the humanitarian field', in Bracken, P. and Petty, C. (Eds.), Rethinking the trauma of war, Free Association Books, Save the Children UK, London and New York, pp.9-37.

Suri, H. (2011) 'Purposeful sampling in qualitative research synthesis', Qualitative Research Journal, Vol. 11, No. 2, pp.63-75.

Thompson, J.L. (2002) 'The world of the social entrepreneur', International Journal of Public Sector Management, Vol. 15, No. 5, pp.412-431.

Treverton, G.F. and Miles, R. (2014) Social Media and Intelligence, Center for Asymmetric Threat Studies (CATS), Swedish National Defence College. [online]. 
http://www.fhs.se/documents/Externwebben/forskning/centrumbildningar/CATS/publikation er/Social\%20Media\%20and\%20Intelligence.pdf.

Tufekci, Z. and Wilson, C. (2012) 'Social media and the decision to participate in political protest: Observations from Tahrir Square', Journal of Communication, Vol. 62, No. 2, pp.363379.

Uzzi, B. (1999) 'Embeddedness in the making of financial capital: How social relations and networks benefit firms seeking financing' American Sociological Review, Vol. 64, No. 4, pp.481-505.

Valenzuela, S. (2013) 'Unpacking the use of social media for protest behavior the roles of information, opinion expression, and activism', American Behavioral Scientist, Vol. 57, No. 7, pp.920-942.

Voida, A., Harmon, E. and Al-Ani, B. (2012) May. Bridging between organizations and the public: volunteer coordinators' uneasy relationship with social computing. In Proceedings of the SIGCHI Conference on Human Factors in Computing Systems, Austin, Texas, USA, pp. 1967-1976.

Weiss, T.G. and Collins, C. (2000) Humanitarian challenges and intervention, Westview Press, Oxford Boulder CO.

Welter, F. and Smallbone, D. (2011) 'Institutional perspectives on entrepreneurial behavior in challenging environments', Journal of Small Business Management, Vol. 49, No. 1, pp.107125.

Wenger, D.E. (1991) Emergent and Volunteer Behavior During Disasters: Research Findings and Planning Implications, Hazard Reduction Recovery Center, A and M University, Texas.

Wolfsfeld, G., Segev, E. and Sheafer, T. (2013) 'Social media and the Arab spring politics comes first', The International Journal of Press/Politics, Vol. 18, No. 2, pp.115-137. 
Table 1. Summary table of Linders (2012)

\begin{tabular}{|c|c|}
\hline $\begin{array}{l}\text { Sequential Stages for co- } \\
\text { creation and co-production }\end{array}$ & Roles of social media \\
\hline $\begin{array}{l}\text { Design and planning } \\
\text { (This stage involves the } \\
\text { mobilisation of key actors to } \\
\text { participate in the cause, work } \\
\text { together and confirm the } \\
\text { idea(s) to pursue and co- } \\
\text { create) }\end{array}$ & $\begin{array}{l}\text { 1. To attract ethically, culturally, and physically diverse } \\
\text { actors, } \\
\text { 2. To provide platforms to them to self-organize, and reduce } \\
\text { co-ordination costs for doing so (Flanagin et al., 2006), } \\
\text { 3.To mobilize them efficiently and effectively to co-create, } \\
\text { and } \\
\text { 4. To facilitate key actors to make strategic decisions. }\end{array}$ \\
\hline $\begin{array}{l}\text { Delivery and execution } \\
\text { (This stage covers the day-to- } \\
\text { day operation of the co- } \\
\text { delivery and co-production } \\
\text { processes. These processes } \\
\text { can take the form of a one-off } \\
\text { transaction, or persistent } \\
\text { collaboration and negotiation } \\
\text { between actors towards the } \\
\text { delivery and execution of } \\
\text { socially } \\
\text { outcomes) }\end{array}$ & $\begin{array}{l}\text { 1. To provides a platform in allowing for closer, deeper and } \\
\text { more frequent collaboration between actors. Collaboratively } \\
\text { developed obligations, expectations and sanctions can be } \\
\text { sustained over time (Downing, 2005; Larson and Starr, } \\
\text { 1993) } \\
\text { 2. To allow each actor to offer particular knowledge and } \\
\text { competencies that can enrich the process of co-delivery in an } \\
\text { effective, efficient and sustainable manner (Banklers, 2006), } \\
\text { 3. To facilitate to manage the actors. }\end{array}$ \\
\hline Monitoring and evaluation & $\begin{array}{l}\text { 1. To facilitate to evaluate relevancy of actors and make } \\
\text { changes in the social order by allowing the actors to leave }\end{array}$ \\
\hline
\end{tabular}




\begin{tabular}{|c|c|}
\hline $\begin{array}{l}\text { situation and the } \\
\text { identification of issues and }\end{array}$ & $\begin{array}{l}\text { 1997; Giddens, 2002; Johannisson, 1996). Such change can } \\
\text { be seen as the adaptive element of the entrepreneurship } \\
\text { process (Jack et al., 2008), with the changes in people } \\
\text { dynamic in turn affecting the co-delivery of the path that the } \\
\text { venture may embark upon (Downing, 2005; Granovetter, } \\
2000 \text { ). Such changes could have the potential to rejuvenate } \\
\text { and catapult the venture beyond the original contextual } \\
\text { boundaries (Johannisson, 1988), enabling them to interact } \\
\text { with the environment more efficiently (Johannisson and } \\
\text { Monsted, 1997). }\end{array}$ \\
\hline
\end{tabular}


Table 2. Information about actors and activities in the social media and its challenges for the social media to overcome

\begin{tabular}{|c|c|}
\hline Information about actors & Challenges for social media \\
\hline $\begin{array}{l}\text { Identification } \\
\text { (Name, personal background, } \\
\text { skills, competencies and } \\
\text { resources) }\end{array}$ & $\begin{array}{l}\text { 1. Obtaining accuracy and authenticity of the } \\
\text { information provided, } \\
\text { 2. Maintaining anonymity of the information. } \\
\text { There is often the danger of infiltration by opposing } \\
\text { bodies that may oppose the view shared by the group } \\
\text { (Fearon, 2008) and hence it is crucial to know the } \\
\text { actual identity of the actors so that the actors with } \\
\text { opposing views could be removed from the network or } \\
\text { the actors with the opposing views could be barred } \\
\text { from joining the network to protect the whole group. }\end{array}$ \\
\hline $\begin{array}{l}\text { Locational } \\
\text { (Location of activities and its } \\
\text { logistical details) }\end{array}$ & $\begin{array}{l}\text { 1. Sensitive information requiring high level of } \\
\text { anonymity. } \\
\text { There is the question of sensitivity with the } \\
\text { dissemination of information in relation to the location } \\
\text { and the logistical arrangements of the actions proposed } \\
\text { (Treverton and Miles, 2014). }\end{array}$ \\
\hline $\begin{array}{l}\text { Tactical } \\
\text { (Explicit and implicit } \\
\text { instructions regarding each } \\
\text { person's involvement, } \\
\text { explaining the tasks that they }\end{array}$ & $\begin{array}{l}\text { 1. Sensitivity, suitability, and enforceability. Without } \\
\text { face-to-face contact it is hard to ensure that the person } \\
\text { (actor) is suitable for the job and that their efforts can } \\
\text { be monitored (Voida et al., 2012). }\end{array}$ \\
\hline
\end{tabular}


are expected to be involved in) 
Table 3. Inclusivity versus exclusivity and network characteristics of Facebook and Twitter

\begin{tabular}{|l|l|l|}
\hline Particulars & Facebook & Twitter \\
\hline Inclusivity & Low & High \\
\hline Exclusivity & High & Low \\
\hline Network tie & Strong & Weak \\
\hline Network size & Small & Large \\
\hline Networks' confidentiality & High & Low \\
\hline
\end{tabular}

Note: This table is developed from Smith et al. (2012) and Sagerberg and Bennett (2011)

Table 4. Coding details for this study

Apriori codes (from Linders, 2012):

- Design and planning

- Delivery and execution

- Monitor and evaluation

Sub-themes developed from Linders 2012

1.0. Idea generation

2.0. Design and planning

2.1. Choice of platform

2.2. Choice of members/ volunteers

2.3.Choice of the relationships with government

2.4.Introducing safe guarding mechanism

3.0.Delivery and execution 
3.1.Setting blueprint

3.2.Distributing workload

3.3.Rule setting

3.4.Procedures

3.5.Financial organisation and financial management

4.0.Monitoring and evaluation

4.1.Reflect on external contextual changes

4.2.Reflect on internal organisational changes

4.3.Reflect on personnel changes 
Table 5 Summary of findings in relation to the three types of co-creation and co-production of social actions

\begin{tabular}{|c|c|c|c|}
\hline & $\begin{array}{l}\text { C2C co-production } \\
\text { of SEVs in a } \\
\text { penurious context }\end{array}$ & $\begin{array}{l}\text { Mobilisation of } \\
\text { political action in a } \\
\text { conflict-related } \\
\text { context }\end{array}$ & $\begin{array}{l}\text { C2C co-production } \\
\text { of SEVs in a } \\
\text { conflict-related } \\
\text { context }\end{array}$ \\
\hline Objective & $\begin{array}{l}\text { To support those } \\
\text { who are affected by } \\
\text { the particular goal } \\
\text { the venture intends to } \\
\text { pursue }\end{array}$ & $\begin{array}{l}\text { To reach the } \\
\text { maximum number of } \\
\text { people as possible }\end{array}$ & $\begin{array}{l}\text { To support those } \\
\text { who are affected by } \\
\text { the particular goal } \\
\text { the venture intends to } \\
\text { pursue }\end{array}$ \\
\hline $\begin{array}{l}\text { Types of media } \\
\text { platform used }\end{array}$ & $\begin{array}{l}\text { Facebook, Twitter, } \\
\text { Governmental e- } \\
\text { platforms }\end{array}$ & $\begin{array}{l}\text { Mostly Twitter, but } \\
\text { also on Facebook } \\
\text { and other social } \\
\text { media outlets }\end{array}$ & $\begin{array}{l}\text { Facebook only } \\
\text { domestically, other } \\
\text { media and social } \\
\text { media outlets } \\
\text { internationally }\end{array}$ \\
\hline $\begin{array}{l}\text { Mobilisation } \\
\text { interest }\end{array}$ & $\begin{array}{l}\text { An open network } \\
\text { intends to mobilise } \\
\text { all, but mostly locals, } \\
\text { who are affected by } \\
\text { the particular goal }\end{array}$ & $\begin{array}{l}\text { An open network } \\
\text { intends to mobilise } \\
\text { all who are affected } \\
\text { by the particular goal } \\
\text { the venture intends to } \\
\text { pursue. This includes }\end{array}$ & $\begin{array}{l}\text { A closed network } \\
\text { intends to mobilise } \\
\text { only those within the } \\
\text { personal network of } \\
\text { those involved. This } \\
\text { includes people who }\end{array}$ \\
\hline
\end{tabular}




\begin{tabular}{|c|c|c|c|}
\hline & $\begin{array}{l}\text { the venture intends to } \\
\text { pursue. }\end{array}$ & $\begin{array}{l}\text { people who are both } \\
\text { locally affected and } \\
\text { those who are further } \\
\text { away and wishing to } \\
\text { support. }\end{array}$ & $\begin{array}{l}\text { are both locally } \\
\text { affected and those } \\
\text { who are further away } \\
\text { and wishing to } \\
\text { support. }\end{array}$ \\
\hline $\begin{array}{ll}\text { Design and } \\
\text { planning }\end{array}$ & $\begin{array}{l}\text { Bottom-up co- } \\
\text { creation, sometimes } \\
\text { being driven by } \\
\text { government agendas. } \\
\text { Opinions are shared } \\
\text { and ideas are then } \\
\text { being put forward by } \\
\text { involved actors }\end{array}$ & $\begin{array}{l}\text { Bottom-up co- } \\
\text { creation } \\
\text { Opinions are shared } \\
\text { and ideas being put } \\
\text { forward by involved } \\
\text { actors }\end{array}$ & $\begin{array}{l}\text { Bottom-up co- } \\
\text { creation } \\
\text { Opinions are shared } \\
\text { and ideas being put } \\
\text { forward by involved } \\
\text { actors }\end{array}$ \\
\hline $\begin{array}{l}\text { Delivery } \\
\text { execution }\end{array}$ & $\begin{array}{l}\text { Considerable } \\
\text { challenges in relation } \\
\text { to delivery } \\
\text { execution, in } \\
\text { particular, how } \\
\text { volunteers are being } \\
\text { managed. Local } \\
\text { collective interest } \\
\text { often becomes the }\end{array}$ & $\begin{array}{l}\text { Considerable } \\
\text { challenges in relation } \\
\text { to delivery and } \\
\text { execution, including } \\
\text { 1) the need to avoid } \\
\text { infiltration from } \\
\text { opposing parties; 2) } \\
\text { handling Slacktivists } \\
\text { who vent their }\end{array}$ & $\begin{array}{l}\text { Challenges reduced } \\
\text { by the pre-screened } \\
\text { nature of the actors } \\
\text { and that they are } \\
\text { being motivated by } \\
\text { shared collective } \\
\text { interest }\end{array}$ \\
\hline
\end{tabular}




\begin{tabular}{|c|c|c|c|}
\hline & $\begin{array}{l}\text { major motivation to } \\
\text { participate. }\end{array}$ & $\begin{array}{l}\text { frustrations online } \\
\text { but perform no } \\
\text { physical action; 3) } \\
\text { Physical danger also } \\
\text { put off some } \\
\text { activists. }\end{array}$ & \\
\hline $\begin{array}{l}\text { Monitoring and } \\
\text { evaluation }\end{array}$ & $\begin{array}{l}\text { Monitor mostly } \\
\text { internal efficiency } \\
\text { rather than change in } \\
\text { external context }\end{array}$ & Cannot be controlled & $\begin{array}{l}\text { Monitor both internal } \\
\text { efficiency and } \\
\text { external change in } \\
\text { context }\end{array}$ \\
\hline
\end{tabular}




\section{Figure 1. Conceptual framework of this study}

Choice of social media outlet (Smith et al., 2012) Implementational Specificities (Linders,

1. Design and planning

2. Delivery and execution

3. Monitor and evaluation

Nature of information obtained under the selected social media

\begin{tabular}{ll}
\cline { 2 - 2 } (Lement, 1981) & $\begin{array}{l}\text { 1. Identification information } \\
\text { 2. Locational information } \\
\text { 3. Tactical information }\end{array}$
\end{tabular}

